\title{
Living in the Shadow of the Bridge: Ivo Andrićs The Bridge on the Drina and Western Imaginings of Bosnia
}

\author{
M A R I N A A N T I Ć
}

Western academics, journalists, and politicians have cited Ivo Andrić so often in support of their theses about a Balkan "essence," especially if that "essence" somehow absolves the West of responsibility for the recent wars in the region, that concluding one's pronouncements about the Balkans with the mention of Andrić's name magically validates those pronouncements, however uninformed or erroneous they might have seemed before. We might agree with the idea that "to learn the primary truths about life in a country and the political rules that can explain its orientations," one should not turn to "historical treatises or extensive political memoirs" but rather to literature - "the poet, the storyteller and the novelist" (Heikal) - and yet, the unparalleled attention paid to Andrić in the story of the Balkans seems to be more than a simple appreciation of literature's role in nation-building. Andrić and his novel The Bridge on the Drina have become codewords in Western academic and political discourse, signaling to an informed audience that the speaker shares with them a secret and thorough knowledge of the Balkans, their history, present, and future.[1] It is my contention that the privileged place Andrić and his novel have in discourse on the Balkans is a result of a particular quasi-colonial reading of The Bridge on the Drina that affirms Western European patterns of perception of Eastern Europe and the Balkans dating back to the early eighteenth century. 


\section{EASTERN EUROPE AND THE BALKANS IN THE WESTERN I M A G IN A T I O N}

Western imaginings of Eastern Europe have always been marked by the ambiguity embodied in the geographic border between Europe and Asia. Larry Wolff correctly observes that "[s] uch uncertainty encouraged the construction of Eastern Europe as a paradox of simultaneous inclusion and exclusion, Europe, but not Europe" (7). Since the eighteenth century, Western travelers and writers have engaged their audiences in the Enlightenment project of defining the "civilized" West against the "barbaric" East. Eastern Europe slowly emerged as a particular transition zone, a bridge between the rational Western European empires and the tyrannical, but respectable Ottoman Empire, a region populated by simple brutes, who could not even understand the tragedy of their own material and moral slavery. Larry Wolff gives us an excellent example of this in Baron François de Tott's travelogue, in which a Western traveler fails to procure food and lodgings from a local "Moravian" by reasoning. The agent of Ottoman colonial power materialized in savage beatings manages to "soften" him, and the peasant is left to testify to the "poverty of his people, extortionately exploited by the hospodar princes." Incidentally, the "hospodar princes" gain more respect from de Tott precisely because of their "skill" in "softening" the peasants. "The three characters of this drama," according to Wolff, "represented Western Europe, Eastern Europe, and the Orient" (72-4).[2]

As Western empires, especially the British, grew in power and the Ottoman Empire entered its final decline, respect for the Ottoman Empire in Western cultural circles diminished (Todorova 91-4). However, Eastern Europe began to acquire an even more important role in the Western ideology of domination. As theories of racial superiority began dominating Western thought in response to the economic domination of the African and American colonies, the population of Eastern Europe began to represent the "missing link" between advanced Western European civilizations and the savage native cultures of Africa, Asia, and the Americas. The transitional character of Eastern Europe thus acquired an even stronger ideological purpose, directly tied to Western European (and later U.S.) economic and political domination of the globe.

Within this tradition of imagining Eastern Europe as a cultural and geopolitical entity, the West "discovered" sometime in the late nineteenth to early twentieth century a special subspecies of this paradoxical, not-quite-European identity in the Balkans. Besides being marked as "the land of the blind, of the night," a semi-savage land suffering under the yoke of barbarism (as Eastern 
Europe had been characterized since the early eighteenth century), the Balkans were now seen as marked by a special propensity for violence that became a mark of their permanent transition, permanent in-between-ness, always "semideveloped, semi-colonial, semi-civilized, semi-oriental" (Todorova 16). This pattern of perception became the dominant one with the Balkan wars, which "shocked" the Western public into ascribing an irrational character to violence in the Balkans. In the eyes of the West, this irrational violent behavior was a consequence of racial mixing in the Balkans, which in turn was a consequence of living between two, in Samuel Huntington's words, "clash[ing] civilizations." The central metaphor that described this Balkan reality was a bridge: a bridge between civilizations, between races, between West and East, between reason and chaos, in essence, a bridge between "us" and "them." [3]

\section{THE BRIDGE ON THE DRINA AS HISTORICAL EVIDENCE} OF THE BALKAN CHARACTER

In light of this history of Western perceptions of the Balkans, it is hardly surprising that Ivo Andrićs The Bridge on the Drina was one of the texts most often cited in Western discussions of the recent wars in the former Yugoslavia. Not only did Andrić in this novel provide ample "evidence" of the "Balkan character" - understood to be the cause of these wars -, but he also referred back to the familiar metaphor of the Balkans as a bridge. For many Westerners, the "wandering ghosts" of the Balkans had once again arisen in Yugoslavia, and could do so at any time in any other part of the haunted peninsula. It was of little significance that the "ghosts" making an appearance in Yugoslavia afflicted no other part of the Balkans - Yugoslav wars were taken to be just a current symptom of an inherently Balkan predicament. Andrićs novel thus became "evidence" of racial and political disorder that marked the Balkans as a place closed to rationality and understanding. It was not possible to "understand" the Balkans rationally, but it was still possible to know them. Like Baron François de Tott, who could not comprehend the Moravian peasant but could still know his character, so the West could not comprehend the reasons behind the war in Yugoslavia but could certainly know that war was inevitable, in part because of the character of the Balkan people that Andrić captured in the tale of civilizations clashing on that famous bridge over the Drina. 
Take, for example, Fitzroy MacLean, an experienced diplomat and the head of the British mission to Yugoslavia during World War II, who declared in an interview for Al Ahram Weekly:

There is one word. I believe it comes from Arabic. It is the only word the Yugoslavians kept from the Ottoman times. [sic] It comes from the Arabic 'inaad. It is charged with connotations. It means staunch resistance, obstinate pride and an overriding tenacity, willingness to make any sacrifice at all, even to the extent of murder or martyrdom. After 'inaad - which is the key to the Yugoslavian personality - there is another key to understanding the history of Yugoslavia. This is The Bridge on the Drina by Ivo Andrić. If you read it, you will discover that the spectacle you see in Yugoslavia now, however strange it may appear, is a natural, vibrant and ongoing echo of history, a past that is still alive (Heikal 3).

There is understanding and even a hint of sympathy in MacLean's words, but the message is unmistakable. A trace of the Ottoman past had found fertile ground in the Slavic character and 'inaad had remained with the peoples of Yugoslavia as part of their hybrid identity, testimony to their inborn militarism and imposed Oriental fanaticism of martyrdom. It is not only their "handicap of heterogeneity" (Roucek, qtd. in Todorova, 128) that causes such spectacle among the Balkan peoples, but also the inability or unwillingness of history to pass, to die and allow progress to take place:

Sometimes I watch what is going on in Yugoslavia and realize that stages of history are still encountering one another in the present. Distant graves are exchanging curses with closer ones. Corpses are rising from beneath the ground, grasping for swords and crying out for old blood. The dead are throttling the dead. (3)

The Bridge on the Drina speaks to MacLean as evidence of the persistence of history in the Balkans. Through Andrić's novel the "strange spectacle" of the wars in former Yugoslavia becomes accessible to Western eyes. Graves, ghosts, and ancient hatreds all surface through Andrić as explanatory and exculpatory evidence for the fate of the region.

Andrić's novel, to a certain extent, lends itself to such (mis)understandings. Benjamin Lambeth begins his book on NATO's mission in Kosovo with several quotations from The Bridge on the Drina:

For informed insight into the origins of the ancestral hatreds that animated the atrocities committed against the Kosovar Albanians by Serbia, one can do no better than the epic novel by Ivo Andrić, The Bridge on the Drina. [...] In a passage hauntingly reminiscent of more recent Balkan horrors, Andrić described how ethnic rivals as far back as the 17th century 'were as if drunk with bitterness, from desire for vengeance, and longed to punish and kill whomsoever they could, since they could not punish or kill those whom they 
wished.' Of a later generation looking at the redrawn map of Bosnia after the Balkan war of 1912, Andrić likewise wrote that they 'saw nothing in those curving lines, but they knew and understood everything, for their geography was in their blood and they felt biologically their picture of the world'.(5)

The Bridge on the Drina does, in fact, speak of ethnic conflicts and wars that have "followed the well-worn paths across the Balkans," (227) as it does of the persistence of history: "[m]any and many of us have sat there, [...] and have unraveled the threads of our small-town destinies, eternally the same yet eternally tangled in some new manner" (20). These passages do open the possibility of understanding the novel as a "guide" through the wars and ancient hatreds in this historically arrested place, but such a reading of the novel ignores both the historical background of Andrićs writing and the politics of the text, which reside beyond the socially symbolic thematic elements.

For example, beginning in 1999, the High Representative appointed to monitor the implementation of the Dayton peace agreement in Bosnia embarked upon a project of modifying or removing "inflammatory content and hatred speech" from textbooks used in Bosnia and Herzegovina (Mukerji). One of the victims of the process was The Bridge on the Drina. In a grammar lesson on the passive voice, the textbook in question contained excerpts from the novel that describe Mehmed Paša Sokolović's trauma at being taken away to serve with the Ottoman Janissaries. Disregarding for a moment the cynical attitude displayed here by Western authorities who find Andrić's novel edifying but apparently too complex or "inflammatory" for the natives to understand, the decision to remove Andrić's text from the curriculum is an excellent example of a reductive political reading of the text.

Mehmed Paša Sokolović's fateful crossing, as well as many other passages in the novel, do, in fact, affirm the Orthodox Christian experience during Ottoman rule in Bosnia. Andrićs sympathy for the Orthodox community is also seen in somewhat subtler assertions of the Orthodox community's myths at the expense of the Muslim community. For example, the Orthodox and Muslim children both have explanations for the spot of barren land on the left bank of the river. The Muslim children believe that "a certain dervish, Sheik Turhanija" died there and his grave is unmarked, waiting for his resurrection in time of need. The Orthodox children believe their hero, Radisav, is buried there. Andrić later reveals that the Orthodox myth is based on history, while the Muslim one is pure invention (57). 
The images of Serbian peasants suffering under Ottoman rule and the affirmation of their experience, while a part of Andrićs personal understanding of history, do not, however, in the last analysis determine the novel's politics. Even if we were to fully analyze Andrić's social perspective in the novel, we would see that Andrić, a supporter of the Young Bosnia movement and a Yugoslavist from an early age, saw the ethnic clashes and wars in Bosnia not as inherent characteristics of the Bosnian or Balkan character, but rather as consequences of the presence of world empires in this small and otherwise insignificant place. The common people for Andrić, sat "head in hands [...] watching the eternal play of light on the mountains and the clouds in the sky" and "unraveled the threads of our small town destinies" (20). The clashes and disagreements among them stem not from some inborn hatred, but rather from the divisions and contradictions created by the empires around them (see also The Days of the Consuls). The Bridge on the Drina is part of Andrićs dialogue with the West, admiring its humanity, on the one hand, and condemning its violence, on the other. $\mathrm{He}$ clearly perceives such violence as having been imposed on the Balkans:

In that summer of 1914, when the rulers of human destinies drew European humanity from the playing fields of universal suffrage to the already prepared arena of universal military service, the town of Visegrad provided a small but eloquent example of the first symptoms of a contagion which would in time become European and then spread to the entire world. (265)

But Andrić's understanding of history, no matter how influential in the development of the novel's themes, does not unequivocally determine the political and social significance of the text. This is not to say that a social, or political interpretation of literature is impossible or even undesirable, but rather, as Theodor Adorno teaches us:

[T]he social interpretation of lyric poetry as of all works of art - may not focus directly on the so-called social perspective or the social interests of the works or their authors. Instead, it must discover how the entirety of a society, conceived as an internally contradictory unity, is manifested in the work of art, in what way the work of art remains subject to society and in what way it transcends it. (38-9)

It is my contention that if we look at the narrative form of The Bridge on the Drina and its interactions with the novel's themes, rather than at Andrićs understanding or representation of history, we discover in what way this novel "remains subject of the society" (and the Balkan reality under the Western gaze) and "in what way it transcends it." If we examine the bridge, that central metaphor of Western perception of the Balkans adopted by Andrić, as a space of identity and a narrative device in the novel, it becomes clear that Andrić's text, if 
it emerges as "historical evidence," does so only as evidence of Andrić's unease with the Western gaze resting on Bosnia.

THE BRIDGE AS A SPACE AND A NARRATIVE DEVICE

There are several important themes in Andrić's novel: the insistence on Bosnia's troubling position between Eastern and Western empires and the trauma of colonial occupation and possession. However, the overarching theme is that of history and its mark on the human psyche. Andrić explores this theme through the interaction of myths and histories of the town, its unconscious desires and psychologies. The bridge as a space and a symbol is always central to this theme. The myths are woven around the bridge's construction, and the psychology of the town is explained by the supra-human presence of the bridge:

So, on the kapia, between the skies, the river and the hills, generation after generation learned not to mourn overmuch what the troubled waters had borne away. There the unconscious philosophy of the town entered them: that life is an incomprehensible marvel, since it is incessantly wasted and spent, and still it lasts and stands strong like the bridge on the Drina.' (81, translation modified)

In Andrić's narrative, the bridge assumes a central position in other ways as well. It has a certain originative role, insofar as the valley and the town emerge from the bridge:

From this bridge spreads fanlike the whole rolling valley with the little oriental town of Visegrad and all its surroundings, with hamlets nesting in the folds of the hills, covered with meadows, pastures and plum orchards, and crisscrossed with walls and fences and aspersed with shaws and occasional clumps of evergreen. (13, translation modified)

Besides being ahistorical and ageless, like the narrator, the bridge is also a historical marker of the town. It is a mark of the historical trauma of colonialism, and of the physical possession of its victims. These historical scars are physical: Mehmed Paša Sokolović feels it as the "black pain which cut into his breast" (26). The bridge, an attempt at resolving that original historical trauma, is an attempt to address history, to come to terms with it, or as Dragan Kujundžić puts it, "an attempt to negotiate or to bridge (and yet keep open) the abyss between the desire to forget the catastrophe of history and its preservation and commemoration" (104). 
The bridge is also a witness to history, for whatever happened in the town, the bridge "still stood unchanged, eternal, untouched, solid and invulnerable." It is in the latter manifestation that the bridge becomes inseparably linked with the narrator. The narrative is, in fact, marked and structured by repetitions of this crucial phrase: the bridge stood unchanged, eternal, and invulnerable. At the end of each epoch and each story woven around the bridge, the narrator reappears from behind his omniscient mask and unites the narrative through reassertions of the bridge's eternity and invulnerability.

The narrator's identification with the bridge leads us to examine another aspect of this "privileged metaphor" that represents Andrićs relationship to history, namely the bridge as a space of identity. Unlike the pruga (line) that cuts Mehmed Paša's chest in two and the pruga (railroad) Austro-Hungarians build to bypass the bridge - two colonial lines that scar Bosnia's history from the sixteenth through the twentieth centuries -, the bridge as a space is neither stable nor determined. The insistence on the bridge's permanence, on its space as the space of one's identity is a reflection of the conditions of the subject in the "colonial" world of the Balkans, caught in-between those determinate lines of colonial possession. The bridge is a space of permanent transition; it always leads beyond, literally and symbolically. Take, for example, Corkan's transcendence of his "small-town destiny" in crossing the parapet of the bridge. It was not just any crossing but "that distant and unattainable voyage of which they had spoken every night at the inn. [...] This was that glorious, long-desired path of great achievement" (199).

In transcendence, the bridge is also always nowhere, in between heaven and earth: "A man was then as if in a magic swing: he swung over the earth and the waters and flew in the skies, yet was firmly and surely linked with the town and his own white house there on the bank with its plum orchard about it" (196-7). The contrast between the bridge as a space and the lines (pruga) that represent the colonial powers on either side of its banks speaks directly to the position of the subject in the Balkans. Being between two empires asserting their linear, clear-cut identities, the Balkan identity is imagined as a bridge: a structure grounded by its banks, but also always hovering somewhere in between them.

In addition, the bridge is a peculiar sort of "dwelling" in Heidegger's terms: it "swings over the stream with 'ease and power.' It does not just connect banks that are already there. The banks emerge as banks only as the bridge crosses the stream. The bridge by design causes them to lie across from each other" (1523). [4] In this sense, the more one tries to determine one's identity in that space of 
permanent transcendence, the more one is grounded by the banks that emerge from it. In other words, the more one tries to conclusively determine one's identity in the Balkans, the more firmly are East and West, as the banks of that Balkan bridge, asserted and the more insistently is one's identity left hanging inbetween those two imaginary geopolitical poles.

\title{
LIVING IN THE SHADOW OF THE BRIDGE
}

In the final scenes of the novel, Austro-Hungarian explosives destroy the bridge. Modernity announces itself in this destructive moment:

\begin{abstract}
In the chaos and disorder of scattered goods and damaged objects that lay in the center of the shop was a heavy stone about the size of a man's head. [...] Alihodja looked again at the stone, white and porous, smooth and clean-cut on two sides but sharp and crudely broken on the other two. 'Ah, the bridge!' thought the hodja. [...] There was no need for him to turn (and he would not have turned for anything in the world) to see the whole picture: in the distance the pier cut short like a gigantic tree-trunk and scattered in a thousand pieces and the arches left and right of it brutally cut short. The broken arches longed painfully towards one another across the break. (311-12, emphasis mine)
\end{abstract}

After four centuries condensed into three hundred pages, the narrator, facing modernity in its full horror, is decapitated before our eyes. The bridge, an embodiment of permanent transition, a symbol of the Western imagination of the Balkans, and the space of the narrator's adopted identity, has been destroyed. This narrative violence testifies to an obsessive neurosis of wishing to escape and being drawn back to the bridge - that indeterminate identity of the Balkans in the eyes of the West. But, in Kafka's words "[w]ithout falling, no bridge, once spanned, can cease to be a bridge" (411): its "essence" asserts itself in the arches that long "painfully towards one another." The story, it seems, is only now beginning.

The politics of The Bridge on the Drina emerges perhaps most forcefully in these final moments. The indeterminacy of the subject's identity in the Balkans, a product of centuries of the West perceiving the Balkans as a hybrid, transitory zone, as well as the material domination of the region by Western and Eastern empires, is expressed in the novel through the metaphor of the bridge. The narrator wishes to escape this ambiguity but cannot. Even self-destructive violence cannot erase the feeling of being "as if on a magic swing" between heaven and earth, not just between East and West. This is perhaps the most powerful commentary on the condition of the subject in the Balkans under the 
Western gaze. For to repetitively assert one's identity in the face of indeterminacy caused by the outsider's gaze is futile: subjectivity ultimately rests with the gaze, not its object. One answer to this dilemma has been to appropriate the colonial gaze and redirect it elsewhere. The Bridge on the Drina suggests, however, that the impossibility of asserting one's subjectivity rests with the impossibility of making the narrative finite: as the arches long painfully towards one another, the bridge/narrator continues to tell and retell the story. The politics of Andric's The Bridge on the Drina thus negates not only ideologically motivated, reductive readings of the text, but also readings of the narrative as a complete and closed political discourse.

\section{E N D N O T E S}

[1] It should be noted here that participation in what I refer to as "Western discourse" is not limited to those residing or even identifying with Western Europe and the United States. Identification of this discourse as Western perhaps speaks more to the domination of a certain perspective in discussions of the Balkans that came about through several centuries of British, French, German, and lastly American "exploration" of the region. It does not seek to assign a stable, unambiguous identity to the "West" as a category nor does it speak directly to the perceived or real hegemony of that self-identified "West." It does, however, accept that self-designation, in a limited sense, as a result of a process that works to establish the "East" and "West" as geopolitical and cultural categories.

[2] For a thorough study of Western perceptions of Eastern Europe, see Larry Wolff, Inventing Eastern Europe: The Map of Civilization on the Mind of the Enlightenment (Stanford: Stanford UP, 1994). Specifically on the topic of the Balkans in the eyes of the West, see Maria Todorova, Imagining the Balkans (New York: Oxford UP, 1997), Vesna Goldsworthy, Inventing Ruritania: The Imperialism of the Imagination (New Haven: Yale UP, 1998), Dušan I. Bjelić and Obrad Savić (eds.), Balkan as Metaphor: Between Globalization and Fragmentation (Cambridge: MIT Press, 2002), and Milica BakićHayden, "Nesting Orientalisms: The Case of Former Yugoslavia," Slavic Review 54, 4 (Winter 1995).

[3] Maria Todorova documents the initial appearance of the bridge metaphor in Western writings about the Balkans, quoting Z. Duckett Ferriman's Greece and the Greeks published in 1911: "[the Greek] is Oriental in a hundred ways, but his Orientalism is not Asiatic. He is the bridge between East and West" (16) and noting another source from 1878 by Karl Emil Franzos, Aus Halb-Asien, Culturbilder aus Galizien, der Bukowina, Südrusland und Rumänien (193).

[4] Dragan Kujundžić first brought this possible connection between Heidegger and Andrić to light in his essay "Ivo Andrić and the Sarcophagus of History" in Ivo Andrić Revisited: The Bridge Still Stands (Berkeley UP, 1995). 


\section{W O RK S C I T E D}

Adorno, Theodore W. "On Lyric Poetry and Society." Notes to Literature, vol. 1. Trans. Shierry Weber Nicholsen. New York: Columbia University Press, 1991.

Andrić, Ivo. The Bridge on the Drina. Trans. Lovett F. Edwards. Chicago: University of Chicago Press, 1977. Trans. of Na Drini ćuprija. Belgrade: Prosveta, 1945.

—. The Days of the Consuls. Trans. Celia Hawkesworth in collaboration with Bogdan Rakić. Boston: Forest Books, 1992. Trans. of Travnička hronika. Belgrade, 1945.

Heidegger, Martin. Poetry, Language, Thought. Trans. Albert Hofstadter. New York: Harper \& Row, 1971.

Heikal, Mohamed Hassanein. "From Myths to Missiles." Trans. Peter Daniel. Ed. Pascale Ghazaleh. Al-Ahram Weekly On-line. Issue 437. 8-14 July 1999. part 1-3. 20 June 2003. $<$ http://www.ahram.org.eg/weekly/1999/437/focus.htm>.

Kafka, Franz. The Complete Stories. Ed. Nahum N. Glatzer. New York: Schocken Books, 1995.

Kujundžić, Dragan. "Ivo Andrić and the Sarcophagus of History." Ivo Andrić Revisited: The Bridge Still Stands. Ed. Wayne S. Vucinich. Research Series 92. Berkeley: International and Area Studies Publications at University of California Berkeley, 1995.

Lambeth, Benjamin S. NATO's Air War For Kosovo: A Strategic and Operational Assessment. Project Air Force Series on Operation Allied Force. Santa Monica: Rand Corporation, 2001.

Mukerji, Vanita Singh. "False Rhetoric and Flawed Logic: Underestimating Literature." Kritika, etc. 2001. 20 June $2003<$ http://www.ac.wwu.edu/ kritika/VSMukerji.htm>.

Todorova, Maria. Imagining the Balkans. New York: Oxford UP, 1997.

Wolff, Larry. Inventing Eastern Europe: The Map of Civilization on the Mind of the Enlightenment. Stanford, CA: Stanford UP, 1994.

Marina Antić is a $\mathrm{PhD}$ student in Comparative Literature at the University of Wisconsin - Madison. Her research interests include Russian and East European languages and literatures, postcolonial studies, and Balkan cultural studies. Contact: mantic@wisc.edu. 
